Golden Gate University School of Law GGU Law Digital Commons

$5-2012$

\title{
Trademark and Copyright Enforcement in the Shadow of IP Law
}

\author{
William T. Gallagher \\ Golden Gate University School of Law, wgallagher@ggu.edu
}

Follow this and additional works at: http:// digitalcommons.law.ggu.edu/pubs

Part of the Intellectual Property Law Commons

\section{Recommended Citation}

28 Santa Clara Computer \& High Tech. L. J. 453 (2012).

This Article is brought to you for free and open access by the Faculty Scholarship at GGU Law Digital Commons. It has been accepted for inclusion in Publications by an authorized administrator of GGU Law Digital Commons. For more information, please contact jfischer@ggu.edu. 


\title{
TRADEMARK AND COPYRIGHT ENFORCEMENT IN THE SHADOW OF IP LAW
}

\author{
William T. Gallagher $\dagger$
}

\begin{abstract}
In recent years; as Congress has created new intellectual property (IP) rights and courts have often interpreted those rights broadly, legal scholars have frequently decried the expanded scope of protection afforded IP owners in most substantive areas of IP law. According to this critique, the over-expansion of IP rights throughout the past two decades harms competition, chills free speech, and diminishes the public domain as increasingly broad areas of social life are brought within the scope of strong IP protection. While this over-expansion theory reflects an important-indeed, foundationalpolicy debate concerning the proper balance between IP owners' rights and the public's rights of access to the information, ideas, and expressions that IP protects, it is incomplete because it focuses largely on what Congress or the courts do. In reality, most enforcement of IP rights takes place not in court, but in the everyday practices of IP owners and their lawyers. "Cease and desist" letters, phone calls, and negotiations with alleged infringers constitute the bulk of IP enforcement efforts in trademark and copyright practice. To be sure, these efforts take place in the "shadow" of IP law and are therefore influenced by it. But it is in these everyday practices-and not in trial or appellate courts-that most IP rights are asserted, resisted, and negotiated. Thus, if we want to know whether IP rights are over-enforced or over-extended, we need to know how, why, and

$\dagger$ Associate Professor of Law and Co-Director of the Intellectual Property Law Program, Golden Gate University School of Law; Visiting Scholar, Center for the Study of Law and Society, University of California, Berkeley School of Law (2009-2011). This paper benefited from comments by numerous individuals during presentations of earlier drafts at: the Center for the Study of Law and Society, U.C. Berkeley School of Law; the IP Scholars Conferences held at the U.C. Berkeley, Stanford, and De Paul Law Schools; the Law and Society Association annual conferences at Berlin, Montreal, and Chicago; and the IP faculty speaker series at the University of Edinburgh School of Law. The author especially wishes to thank the attomey respondents who participated in this study. This study was generously supported by faculty research funds from the Golden Gate University School of Law.
\end{abstract}


to what effect these rights are exercised in the everyday practices of IP owners and their lawyers. To date, however, IP scholarship has focused virtually no attention on this critical arena of everyday practice.

This Article presents findings from a qualitative empirical study of the trademark and copyright disputing process outside of court, based on original data derived from semi-structured interviews with experienced IP attorneys who advise clients on how to enforce their rights. This research is one of the first studies to examine how trademark and copyright claims are actually enforced in practice. One significant finding from this study is that "repeat player" trademark and copyright owners (and their lawyers) knowingly assert weak IP claims at times-precisely because it works, as enforcement targets are unable or unwilling to resist claims that may lack legal merit due to the costs and uncertainties of threatened litigation. Moreover, the lawyers who assert weak IP claims have ready practical and ethical justifications for their actions. This study also suggests that legal sanctions directed at deterring over-reaching IP enforcement are unlikely to be effective because most such overreaching occurs in informal disputing processes outside of the legal system. 


\section{INTRODUCTION: UNDERSTANDING IP ENFORCEMENT AND ITS CONSEQUENCES}

In recent years, as Congress has created new intellectual property (IP) rights and courts have often interpreted those rights broadly, legal scholars have frequently decried the expanded scope of protection afforded IP owners in most substantive areas of IP lawincluding patents, ${ }^{2}$ copyrights, ${ }^{3}$ trademarks, ${ }^{4}$ and rights of publicity. ${ }^{5}$ According to this critique, the over-expansion of IP rights throughout the past two decades harms competition, chills free speech, and diminishes the public domain as increasingly broad areas of social life are brought within the scope of strong IP protection. ${ }^{6}$ While this overexpansion theory reflects an important-indeed, foundational-policy debate concerning the proper balance between IP owners' rights and the public's rights of access to the information, ideas, and expressions

1. See, e.g., JeSSICA LITMAN, Digital COPYRIGHT (2001); Mark A. Lemley \& Mark P. McKenna, Owning Mark(et)s, 109 MICH. L. REV. 137 (2010) (critiquing trademark law's expansion in court decisions that unduly broaden trademark owners' rights); Sarah Mayhew Schlosser, The High Price of (Criticizing) Coffee: The Chilling Effect of the Federal Trademark Dilution Act on Corporate Parody, 43 ARIZ. L. REv. 931 (2001).

2. See, e.g., Andrew Beckerman-Rodau, The Problem with Intellectual Property Rights: Subject Matter Expansion, 13 YALE J.L. \& TECH. 35, 54-62 (2010) (summarizing and critiquing the expansion of the scope of patent law).

3. See, e.g., Ronald V. BetTig, Copyrighting Culture: The Political ECONOMy of Intellectual Property (1996); Lawrence Lessig, free Culture: The Nature and

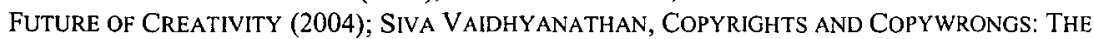
Rise of intellectual Property and How It Threatens Creativity (2001); BeckermanRodau, supra note 2, at 63-66.

4. See, e.g., Rosemary J. CoOmbe, The Cultural life of Intellectual PROPERTIES: AUTHORSHIP, APPROPRIATION, AND THE LAW (1998); Beckerman-Rodau, supra note 2, at 67-72; see also Leah Chan Grinvald, Shaming Trademark Bullies, 2011 WIS. L. REV. 625,632 (summarizing modern expansion of trademark law in favor of expansive rights for trademark owners).

5. See, e.g., COOMBE, supra note 4; K.J. Greene, Intellectual Property Expansion: The Good, the Bad, and the Right of Publicity, 11 CHAP. L. Rev. 521 (2008); Michael Madow, Private Ownership of Public Image: Popular Culture and Publicity Rights, 81 CALIF. L. REV. 127 (1993).

6. See, e.g., James Boyle, The Public domain: Enclosing the Commons of the Mind (2008); JoanNa Demers, STEal This Music: How InTEllectual Property laW Affects Musical Creativity (2006); BetTig, supra note 3; Thomas F. Cotter, Fair Use and Copyright Overenforcement, 93 lowA L. REv. 1271 (2008); Michael J. Meurer, Controlling Opportunistic and Anti-Competitive Intellectual Property Litigation, 44 B.C. L. REv. 509 (2003) (examining the potential anti-competitive effects produced when IP owners enforce nonmeritorious claims in litigation). 
that IP protects, ${ }^{7}$ it is incomplete precisely because it focuses largely on what Congress or the courts do. In reality, most enforcement of IP rights takes place not in court, but in the everyday practices of IP owners and their lawyers. " "Cease and desist" letters, phone calls, and negotiations with alleged infringers constitute the bulk of IP enforcement efforts in trademark and copyright practice. ${ }^{9}$ To be sure, these efforts take place in the "shadow" of IP law and are therefore influenced by it. ${ }^{10}$ But it is in these everyday practices-and not in trial or appellate courts-that most IP rights are asserted, resisted, and negotiated. Thus, if we want to know whether IP rights are overenforced or over-extended, we need to know how, why, and to what effect these rights are exercised in daily life. ${ }^{11}$ To date, however, IP scholarship has focused virtually no attention on this critical arena of everyday practice. $^{12}$ Most IP scholarship is primarily doctrinal,

7. See, e.g., Robert P. MERges, Justifying Intellectual Property (2011). Not all scholars agree with the over-expansion critique. See, e.g., Marc H. Greenberg, Reason or Madness: A Defense of Copyright's Growing Pains, 7 J. Marshall ReV. INTEll. Prop. L. 1 (2007).

8. See, e.g., James Gibson, Risk Aversion and Rights Accretion in Intellectual Property Law, 116 YALE L.J. 882 (2007) (theorizing that the contemporary over-expansion of IP rights stems not only from court decisions and congressional enactments but also from private behavior in licensing of IP that results in "rights accretion"); see also Ira S. Nathenson, Civil Procedures for a World of Shared and User-Generated Content, 48 U. LOUISVILLE L. REV. 911 (2010) (theorizing how over-enforcement of copyrights may result from private enforcement practices outside of court).

9. See infra Part III.

10. See Robert H. Mnookin \& Lewis Kornhauser, Bargaining in the Shadow of the Law: The Case of Divorce, 88 YALE L.J. 950 (1979) (explaining how formal law affects private negotiated settlements of legal disputes that are thus influenced and shaped by law's "shadow").

11. The IP over-enforcement thesis is not just the subject of academic discussion, it has made its way into popular culture as well. See, e.g., Darrin Bell, Tweetmark, CANDORVILLE (Oct. 22, 2011), http://candorville.com/2011/10/22/tweetmark/.

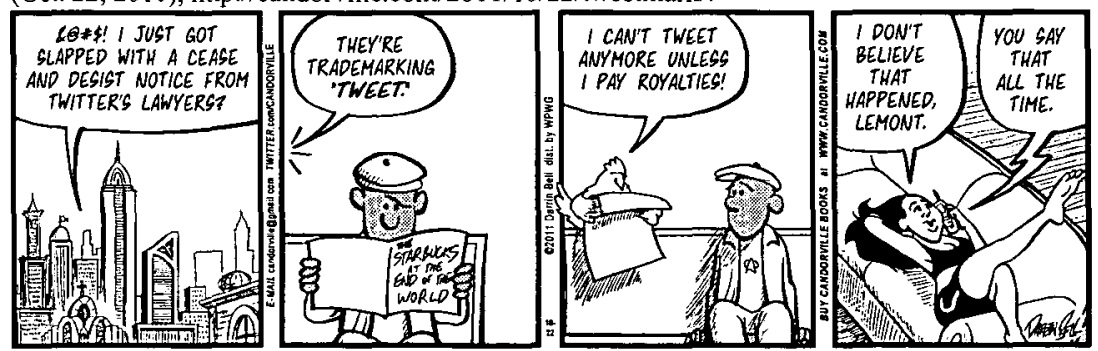

12. Some scholars have argued that $\mathrm{IP}$ rights are overextended due to overreaching by IP owners who assert claims of dubious legal merit, but these arguments are not based on systematic empirical study of IP enforcement efforts outside of court. See, e.g., JASON

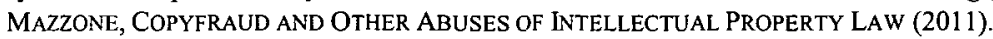


focusing on published appellate cases. ${ }^{13}$ Even the growing empirical scholarship on IP focuses largely on published or, at least, filed cases. ${ }^{14}$ As in every other area of civil justice, however, most IP disputes do not result in litigation, and most litigation settles well before trial. ${ }^{15}$ Certainly, published appellate decisions and even filed cases represent only a small percentage of IP disputes. Thus, in order to more fully understand whether IP rights affect competition, chill free speech, diminish the public domain, or impede creativity, it is necessary to explore how IP claims are made and resolved in private negotiation rather than in litigation, which is the focus of this Article. It presents findings from a qualitative empirical study of the trademark and copyright disputing process outside of court, based on original data derived from semi-structured interviews with experienced IP attorneys who advise clients on how to enforce their rights. This research is one of the first studies to examine how trademark and copyright claims are actually enforced in practice.

\section{A. From Bobbleheads to Bullies}

One impetus for the present research was the outcome of a widely reported IP case that presented important legal issues of first impression, but which settled before those issues were adjudicated in court. ${ }^{16}$ Although this case did not involve trademarks or copyrights, its resolution highlighted how IP owners may be able to use the threat of litigation to coerce advantageous settlements outside of court, even in cases where the asserted IP rights are weak or where the courts would likely limit those rights in litigation. The case and its lessons thus merit brief discussion here.

In 2004, Oak Productions, Inc. ("Oak Productions"), the licensing company for then-California Governor and Hollywood

13. See, e.g., Rosemary J. Coombe, Commodity Culture, Private Censorship, Branded Environments, and Global Trade Politics: Intellectual Property as a Topic of Law and Society Research, in THE BLACKWEll COMPANION TO LAW AND SOCIETY 369 (Austin Sarat ed., 2004) (stating that most IP scholarship focuses on doctrinal analysis or theorizing about IP from economic or philosophical perspectives).

14. See, e.g., Barton Beebe, An Empirical Study of U.S. Copyright Fair Use Opinions, 1978-2005, 156 U. PA. L. REV. 549 (2008); Barton Beebe, An Empirical Study of the Multifactor Tests for Trademark Infringement, 94 CAL.IF. L. REV. 1581 (2006); Kenneth L. Port, Trademark Extortion: The End of Trademark Law, 65 WASH. \& LEE L. REV. 585 (2008).

15. See infra Part III.A.

16. See Complaint at 5-6, Oak Prods., Inc. v. Ohio Disc. Merch., Inc., No. SC081563 (Los Angeles Super. Ct. filed Apr. 30, 2004). In the interest of full disclosure, I should note that I served as lead defense counsel for ODM in this litigation. 
movie star Arnold Schwarzenegger, filed a lawsuit in Los Angeles against a small Ohio manufacturing company, Ohio Discount Merchandise ("ODM"), that made and sold bobblehead dolls depicting Schwarzenegger dressed in a suit while brandishing an automatic rifle and bandolier of bullets. ${ }^{17}$ At the time, ODM made and sold online an entire line of politician bobblehead dolls in addition to a variety of other dolls depicting historical figures, cartoon characters, and contemporary celebrities. ${ }^{18}$ ODM licensed the rights to use the likenesses for most of these dolls, but did not acquire licenses for the dolls depicting political figures, believing that these uses were protected as free speech under the First Amendment. When Oak Productions learned of the new Schwarzenegger bobblehead, it sent ODM a letter claiming that its sales of the doll violated California's right of publicity laws ${ }^{19}$ and demanding that ODM immediately cease all sales of the doll. ${ }^{20}$ The letter itself took a particularly aggressiveindeed, over-the-top-tone, stating in conclusion that the letter itself was protected by copyright and any reproduction of it would therefore constitute copyright infringement. ${ }^{21}$ Rather than persuading ODM to comply with its demands, Oak Productions apparently provoked ODM into posting the letter online. In response, Oak Productions filed a lawsuit against ODM in state court alleging violations of Schwarzenegger's rights of publicity. The Schwarzenegger

17. For a picture of the doll, see Tyler T. Ochoa, The Schwarzenegger Bobblehead Case: Introduction and Statement of Facts, 45 SANTA CLARA L. REV. 547, 675 (2005). In that article, Professor Ochoa summarizes the main facts and issues raised by this case. These issues are analyzed by the plaintiffs' and defendants' counsel in this case and by legal academics. See William T. Gallagher, Strategic Intellectual Property Litigation, the Right of Publicity, and the Attenuation of Free Speech: Lessons from the Schwarzenegger Bobblehead Doll War (And Peace), 45 Santa Clara L. Rev. 581, $581-82$ (2005); Shubha Ghosh, On Bobbling Heads, Paparazzi, and Justice Hugo Black, 45 SANTA ClARA L. REV. 617, 642 (2005); Charles J. Harder \& Henry L. Self III, Schwarzenegger vs. Bobbleheads: The Case for Schwarzenegger, 45 SaNTA ClaRA L. REV. 557, 558 (2005); David S. Welkowitz \& Tyler T. Ochoa, The Terminator as Eraser: How Arnold Schwarzenegger Used the Right of Publicity to Terminate NonDefamatory Political Speech, 45 SANTA ClaRA L. REV. 651, 651-54 (2005); see also 1 J. ThOMAS MCCARTHY, The RIGHTS OF PUblicity AND PRIVACY, 240-41 (2011) (discussing the Schwarzenegger Bobblehead Case).

18. Tyler T. Ochoa, The Schwarzenegger Bobblehead Case: Introduction and Statement of Facts, 45 SANTA ClaRA L. REV. 547, 550-51 (2005).

19. See CAL. CIV. CODE $\$ 3344$ (a) (setting forth Califomia statutory rights of publicity). California also recognizes common law rights of publicity. See, e.g., Comedy III Prods., Inc. v. Saderup, Inc., 25 Cal. 4th 387 (Cal. 2001).

20. See Letter from Martin D. Singer, Oak Productions, Inc.'s counsel, to Todd D. Bosley, President, Ohio Discount Merchandise, Inc. (Apr. 29, 2004) (on file with author).

21. Id. 
bobblehead doll case caused an immediate and worldwide reaction in the press, radio, and television, ${ }^{22}$ with most of the stories calling on Oak Productions (and Schwarzenegger) to back down from such aggressive litigation tactics. ${ }^{23}$

While this case no doubt generated such a strong journalistic response due to Schwarzenegger's celebrity power, it also raised important legal issues of first impression concerning the proper scope of the right of publicity for sitting politicians. ${ }^{24}$ Never before had an in-office politician actually sued under right of publicity law, even if several politicians over the years threatened such lawsuits. ${ }^{25}$ Although the lawsuit raised such important and unresolved legal issuesincluding the central issue of whether this type of IP should be used to censor non-defamatory speech about a political figure ${ }^{26}$ - it settled, as most cases do ${ }^{27}$ leaving these issues to be debated by academics and practitioners. Yet one of the more general lessons from the bobblehead case that is pertinent to the issues highlighted in this Article is how powerful IP rights owners, as sophisticated "repeat players" in IP enforcement efforts against often "one-shot" participants in the legal system, have strategic advantages that allow them to enforce IP rights beyond their proper scope. After the bobblehead case settled, I argued that Oak Productions had been able to assert weak IP rights to compel a settlement precisely because of these strategic advantages, and I urged legal academics to study how IP rights were asserted, resisted, negotiated, and litigated in everyday practice. ${ }^{28}$ This Article, and the ongoing research project of which it is

22. See Ochoa, supra note 18 , at 547 n.1.

23. See, e.g., Editorial, Whiplash, N.Y. TiMES, May 24, 2004, at A22.

Mr. Schwarzenegger has every right to claim full legal ownership of himself and his image as an actor and to guard it jealously against infringement. It's a little tougher for him to do so as a politician. A company cannot legally make money by selling ordinary Schwarzenegger merchandise without his permission. But it can do so if something is done to the image to make it satirical or a commentary. That's something political figures have to learn to live with.

Id.

24. See MCCARTHY, supra note 17 , at $236-48$.

25. Id.

26. See Welkowitz \& Ochoa, supra note 17

27. Ochoa, Introduction and Statement of Facts, supra note 17, at 547, 554-56.

28. Gallagher, supra note 17, at 610-15. I also argued that the public settlement statement in that case demonstrated that the issue perplexing plaintiffs was not whether the ODM Schwarzenegger bobblehead doll was authorized or not, but that it depicted Schwarzenegger in an unflattering manner (at least unflattering to him, apparently). This is indicated by the settlement language that states that ODM will sell an authorized Schwarzenegger doll without a 
a part, is one attempt to do just that.

More recently, other legal scholars have begun to pay attention to what they term IP "bullies"-IP owners who assert, often successfully, rights that are arguably weak on the legal merits. ${ }^{29}$ These scholars argue that such enforcement efforts can be very effective precisely because they typically include threats of litigation that many companies (and most individual targets of such threats) cannot afford to resist because of the legal uncertainties in many areas of IP law and because of the often enormous potential costs of IP litigation. $^{30}$ One contribution of the present study is to explore systematically this ubiquitous, yet virtually unexamined, arena of IP enforcement activity.

This Article presents findings from a qualitative empirical study of how trademarks and copyrights are enforced (or, sometimes, not enforced) in everyday practice. This research is part of a larger project that seeks to map, analyze, and theorize the landscape of enforcement practices in patent, trademark, and copyright disputes. ${ }^{31}$ Based on original empirical data derived from 58 in-person interviews with experienced lawyers who regularly enforce trademark and copyright claims on behalf of IP owners, this Article explores and analyzes the IP disputing process in everyday trademark and copyright practice. It offers a unique window into an area of law that is vastly underexamined and under-theorized in IP scholarship.

The Article proceeds as follows: Part II discusses the methodology employed in this study. Part III maps the stages of the IP disputing process outside of court and identifies the legal and nonlegal factors that influence lawyers and their clients when determining

gun. Gallagher, supra note 17 , at 611 . That appears to be a strong admission that the objectionable part about the doll was its message, not that it was unlicensed.

29. See, e.g., Grinvald, supra note 4; Ted M. Sichelman, The Vonage Trilogy: A Case Study in "Patent Bullying", in PERsPectives on PATENTABle SubJeCt MatTer (Michael Abramowicz, John Duffy \& F. Scott Kieff eds., 2011) (forthcoming). For popular press examinations of the IP "bully" phenomenon, see DAVID BOLliER, BRAND NAME BULLIES: THE Quest TO OWN AND CONTROL CULTURE (2005).

30. See, e.g., sources cited supra note 29.

31. The full project examines the strategic acquisition and enforcement of patents, trademarks, and copyrights. One version of the patent law study focuses primarily on ethical issues in patent litigation. See William T. Gallagher, IP Legal Ethics in the Everyday Practice of Law: An Empirical Perspective on Patent Litigators, 10 J. MARSHAll ReV. INTElL. PROP. L. 309 (2011). The second patent enforcement study is forthcoming, as is one related project focusing on the strategic acquisition of patent rights, which examines the practices of patent prosecutors. The broader empirical research project as a whole aims to develop a comprehensive understanding of how IP rights are acquired and enforced in actual practice. 
whether and how to enforce IP rights and against which targets. Part IV presents some of the most important and provocative findings of this study. It examines how private IP enforcement practicesprimarily "cease and desist" letters and threats of litigation during the course of negotiations - are strategically used to settle disputes, often resulting in a target's decision to capitulate to the asserted IP claims. This section also shows that non-meritorious trademark and copyright claims are indeed enforced successfully in many cases, thus substantiating the thesis that IP rights are over-enforced in practice under the radar of the courts and the formal legal system. Part IV also examines the lawyer's role in the knowing assertion of nonmeritorious or weak IP claims as well as the ethical reasoning lawyers employ to justify such tactics, even when they go against the lawyer's better legal judgment. Part IV concludes by exploring whether repeatplayer enforcers have strategic advantages in IP disputing, and under what circumstances "bullying" tactics are effective (or not) in asserting trademark and copyright claims. Part V recaps the major findings of this study and outlines the need for further empirical, multi-method analysis of the IP disputing process in light of the present study's findings.

\section{Methodology}

This Article is based on original data from semi-structured, inperson interviews with experienced lawyers who regularly enforce trademarks and copyrights on behalf of their clients. Because the research questions involved understanding how, why, and to what effect IP rights are enforced by trademark and copyright owners, the study asked experienced IP lawyers to explain how they and their clients understand and make decisions at each stage of the pretrial IP enforcement process. ${ }^{32}$ Although interview-based research has been used extensively in many areas of socio-legal research, ${ }^{33}$ there is very

32. Of course, an alternative approach would be to interview the $\mathbb{P}$ owners directly. That method was rejected only because of lack of sufficient access to large, mostly corporate owners of trademark and copyright portfolios who regularly enforce their IP rights. Although the interviewed lawyers' statements about client reasoning, understandings, and strategy are often insightful, it must be understood in light of this limitation.

33. For example, there is a rich scholarly literature on the legal profession, much of which is based on both quantitative and qualitative empirical data (including interviews). See, e.g., Gallagher, supra note 31, at 313-14 (surveying empirical studies of lawyers in various practice settings). For several recent examples of studies of lawyers that effectively use interview data, see HERBERT M. KRITZER, RISKS, REPUTATIONS, AND REWARDS: CONTINGENCY Fee Legal Practice in the United States (2004); Lynn Mather, Craig A. McEwen \& 
little such research focused on IP lawyers and practices. ${ }^{34}$ This section discusses the methodology for this study, including an assessment of the strengths and limits of this type of qualitative empirical research.

\section{A. A "Law and Society" Perspective on IP}

This study also aims to further a broader goal of developing a law and society approach to studying intellectual property. ${ }^{35}$ Such an approach emphasizes the study of law "in action"-as it operates in society and culture. A law and society approach also studies law, legal actors, institutions, processes, and cultures empirically, primarily using methods developed in social science disciplines, including political science, sociology, anthropology, history, and cultural studies. ${ }^{36}$ Despite the importance and prominence of intellectual property, it remains an area of law and social practice that has not been well examined by law and society scholars. ${ }^{37}$

This approach stresses the need to understand how law operates from the bottom-up and in everyday practice. ${ }^{38}$ The law and society approach to the study of IP is particularly important precisely because it is an area of law that remains greatly under-studied and undertheorized from this perspective. ${ }^{39}$

RICHARD J. MaIMAN, DIVORCE LaWyers at WORK: VARIETIES OF PROFESSIONALISM IN Practice (2001); Austin Sarat \& William L. F. Felstiner, Divorce LaWyers and Their Clients: Power and Meaning in the Legal Process (1995).

34. For an excellent example of such research, see John M. Conley \& Lynn Mather, Scientists at the Bar: The Professional World of Patent Lawyers, in LAWYERS IN PRACTICE: ETHICAL DECISION MAKING IN CONTEXT 245 (Leslie C. Levin \& Lynn Mather eds., 2012).

35. For an overview of what constitutes a "law and society" perspective, see KITTY Calavita, InVITATION to LaW \& SOCIETY: AN INTROdUCTION TO THE STUdy OF REAL LaW (Leslic C. Levin \& Lynn Mather eds., 2010); SIMON HALlidAY \& PATRICK SCHMIDT, CONDUCTNG LAW AND SOCIETY RESEARCH: REFLECTIONS ON METHODS AND PRACTICES (2009); CARROLl SERON, THE LAW AND SOCIETY CANON (Carroll Seron ed., 2006); Lawrence M. Friedman, The Law and Society Movement, 38 STAN. L. REV. 763 (1986) (discussing what constitutes a "law and society" approach to the study of law); Bryant Garth \& Joyce Sterling, From Legal Realism to Law and Society: Reshaping Law for the Last Stages of the Social Activist State, 32 LAW \& SoC'Y REV. 409 (1998). See also William T. Gallagher, What Is a "Law and Society" Perspective on Intellectual Property Law?, in INTELLECTUAL PROPERTY xi (William T. Gallagher ed., 2007) (arguing for how this perspective should be applied to the study of intellectual property).

36. See sources cited supra note 35 .

37. There are some notable exceptions. See, e.g., Peter Drahos, THE Global Governance of Knowledge: Patent Offices and Their Clients (2010); Peter Drahos \& John Braithwaite, INFORMATION FEUdALISM: WhO OWNS THE KNOWLEDGE ECONOMY? (2002); see also Coombe, supra note 13.

38. See, e.g., sources cited supra note 37

39. See Peter Cane \& Herbert M. Kritzer, Introduction, in THE OXFord HANDBooK of 


\section{B. Semi-Structured Interviews}

The interviews for this study were conducted between 2005 and 2010, with the majority of them held between 2006 and 2009. A total of 58 interviews were completed. All but five of these interviews took place in person, typically in the interviewed lawyer's office. The remaining five interviews were conducted by telephone. The lawyers all agreed to have their interviews recorded and transcribed for purposes of this study, although all interview information that could identify an individual lawyer or client was omitted from the transcripts. ${ }^{40}$ The interviews were semi-structured, meaning that the interview schedule generally followed the same set of topics and questions in the same order, but not all interviews ultimately included all topics and any particular interview was allowed to develop as the discussion took place and issues were probed. ${ }^{41}$ Interviews lasted from about one hour to three hours in duration. Most of the interviews lasted from about one and a half to two hours. The recorded interviews were transcribed and analyzed using qualitative research software, ${ }^{42}$ which made coding, organizing, and analysis ${ }^{43}$ of the interview transcripts easier and more systematic. ${ }^{44}$

All empirical research has strengths and limits, and all such research must deal with validity and reliability issues. ${ }^{45}$ Among the

EMPIRICAL Legal ReSEARCh (Peter Cane \& Herbert M. Kritzer eds., 2010) (explaining that several areas of law, including intellectual property, remain under-examined empirically); see also Coombe, supra note 13 (discussing how most scholarship on intellectual property law is based on doctrinal, economic, or philosophical analysis and arguing for the need to study intellectual property from interdisciplinary, law and society perspectives).

40. This was done in order to facilitate the lawyers' agreements to be interviewed and to have the interviews recorded.

41. For an excellent example of a semi-structured interview schedule, see MATHER ET AL., supra note 33. The interview schedule for this study of divorce lawyers is available on the law school web page for Professor Mather. See Interview Schedule for Divorce Lawyers, SUNY BUFFALO LAW SCHOOL, http://www.law.buffalo.edu/Faculty_And_Staff/submenu/profiles/mather_lynn/interview_questi ons.pdf (last visited Mar. 6, 2012) (copy on file with author).

42. I used NVivo 8 software for this study.

43. For a discussion of coding and analysis of qualitative data, see CARL F. AUERBACH \& LOUISE B. SILverstein, QualitaTIVE DATA: AN INTRODUCTION to CoDING AND ANALYSIS (2003).

44. On using software in qualitative research generally, see ANN LEWINS \& CHRISTINA SILVER, USING SOFTWARE IN QUALITATIVE RESEARCH: A STEP-BY-STEP GuIDE (2007).

45. For a discussion of strengths and weaknesses of both quantitative and qualitative empirical legal studies, see, for example, Lee Epstein \& Andrew D. Martin, Quantitative Approaches to Empirical Legal Research, in THE OXFORD HANDBOOK OF EMPIRICAL LEGAL RESEARCH 901 (Peter Cane \& Herbert M. Kritzer eds., 2010); Laura Beth Nielsen, The Need for 
strengths of interview-based research ${ }^{46}$ is the ability to probe issues and statements in-depth, particularly with follow-up questions and requests for concrete examples from particular cases. ${ }^{47}$ The interviewed lawyers for this study were generous with their time and were quite willing to talk about themselves, their practices, and the law. As a result, many of the interviews contained rich detail for analysis. Of course, there are limits to interview-based research. The interviewed lawyers may have selective memories or provide statements about what they "usually" do rather than what they actually do. ${ }^{48}$ But a good interviewer should be aware of these possibilities and probe responses to get concrete examples of what was done (and why) in particular cases in order to minimize such limitations.

\section{Sampling and Lawyer Characteristics}

The 58 interviewed lawyers were selected by a non-random "snowball" sampling technique ${ }^{49}$ designed to identify lawyers with more than five years of experience enforcing trademarks and copyrights and who currently practiced more than $50 \%$ of the time in this area. Lawyers identified in the snowball sample were then contacted by letter asking them to participate in this study. The letters were followed up by a phone call. The response rate for this study was very high, as all but one lawyer who was contacted by telephone agreed to participate. Only three lawyers who agreed to participate were not interviewed, mostly due to scheduling issues. ${ }^{50}$

Multi-Method Approaches in Empirical Legal Research, in THE OXFORD HANDBOOK OF EMPIRICAL LEgal RESEARCH 951 (Peter Cane \& Herbert M. Kritzer eds., 2010); Lisa Webley, Qualitative Approaches to Empirical Legal Research, in THE OXFORD HANDBOOK OF EMPIRICAL LEGAL RESEARCH 926 (Peter Cane \& Herbert M. Kritzer eds., 2010).

46. For a general discussion of semi-structured interview methodology, see TOM WENGRAF, QUALITATIVE RESEARCH INTERVIEWING: BIOGRAPHIC NARRATIVE AND SEMISTRUCTUREd METHOdS (2001). See also NigEl KING \& CHRISTINE HORROCKS, INTERVIEWS IN QuALITATIVE RESEARCH (2010).

47. Asking for examples also helps ground the discussions in actual case facts, thus potentially minimizing the risk that interviewees simply provide idealized or overly-generalized conclusion as to what they usually do, as opposed to what they actually did in a particular instance.

48. One way to capture what these lawyers actually do would be to do an observational study with follow-up interviews. See, e.g., KRITZER, supra note 33, at 19-22.

49. See Rowland Atkinson \& John Flint, Snowball Sampling, in 3 THE SAGE ENCYCLOPEDIA of SOCIAL SCIENCE RESEARCH METHOdS 1043-44 (Michael S. Lewis-Beck et al. eds., 2004).

50. In sum, sample identified a total of 62 potential lawyers to interview. All 62 were 
All of the interviewed lawyers practiced in California-one of the most sophisticated legal markets for IP law and lawyering in the world. All of the lawyers had at least five years of experience dealing with trademark and copyright enforcement, and their years of IP practice experience ranged from five to forty years, with most having practiced in this area between twelve and twenty-five years. About three-quarters of them (45) were partners in law firms of varying sizes, ranging from boutique firms of three lawyers to large firms with hundreds of lawyers in multiple cities. Most of the remainder (7) had "of counsel" status, although four of the lawyers were solo practitioners (all of whom had previously worked in either large law firms or as in-house counsel specializing in IP), and two lawyers served as in-house counsel in corporate legal departments. There were slightly more men (31) than women (27) in this study. ${ }^{51}$ One characteristic of the interviewed lawyers stands out precisely because it highlights one of the distinguishing features of trademark and copyright practice: almost all of the study lawyers had relatively little trial experience (and more than one-third had never been to trial in a trademark or copyright case in their entire career).$^{52}$ Only five lawyers indicated that they had gone to trial in a trademark or copyright case more than three times in their careers. ${ }^{53}$ This finding perhaps reflects the general phenomenon of "the vanishing trial" in civil cases. ${ }^{54}$ But it also highlights that most trademark and copyright disputing occurs outside of court and, even when a lawsuit is filed, most disputes settle at some point in the pretrial stage. ${ }^{55}$ As discussed more fully below,

contacted by letter and telephone. Only one declined to participate in the study. All of the remaining lawyers agreed that they were experienced trademark or copyright lawyers and stated that they would participate in the study interviews. Ultimately, three of these lawyers were not interviewed before the completion of the study.

51. This gender balance is in sharp contrast to the companion study of patent litigators, most of whom were male. See Gallagher, supra note 31, at 318 .

52. I excluded Trademark Trial and Appeal Board "trials" from this calculation, since such trials are not conducted in person.

53. Four additional lawyers indicated that they had cases that proceeded to trial over the years, but that they turned these cases over to other lawyers once it appeared the cases would not settle and would proceed to trial.

54. See Marc Galanter, The Vanishing Trial: An Examination of Trials and Related Matters in Federal and State Courts, 1 J. OF EMPIRICA'L LEGAL STUD. 459 (2004).

55. See William M. Landes, An Empirical Analysis of Intellectual Property Litigation: Some Preliminary Results, 41 Hous. L. REV. 749, 758-62 (2004). Note that this data is limited to filed cases. The present study suggests that most trademark and copyright disputes simply do not result in litigation, highlighting the need to understand this under-examined landscape of everyday IP disputing. 
that reality strongly shapes how lawyers and their clients act in trademark and copyright disputing.

The industries represented by the trademark and copyright clients of the interviewed lawyers were a mix. These lawyers represented clients in many industries, including high-tech (including Internet and software), music recording, consumer goods, publishing, telecommunications, wine, and movie studios, among others. With such a mix of lawyers and clients, the interviews provided a wide window on trademark and copyright enforcement. ${ }^{56}$

\section{THE IP Disputing Process IN THE Shadow of THE LAW}

The "disputing process" paradigm has its roots in pioneering anthropological studies of disputing outside of the formal legal system in tribal societies. ${ }^{57}$ The paradigm has also been employed to study how disputes arise and are handled-also mostly outside of formal legal institutions-in a variety of other settings, including contemporary complex societies. ${ }^{58}$ The disputing process paradigm has significantly influenced a great deal of "law and society" research. Indeed, some scholars have described it as producing "[a] body of work that gave distinctive shape and substance to the field of law and society . . . by looking outside of courts, or any other formal institutions of law." 59 This study uses a dispute processing focus to

56. There is always more to do for another day in this type of research. The present study included both trademark and copyright disputing as its focus, primarily because of the concern that over-enforcement in these areas of practice may have a harmful effect on free speech and the public domain-and both of these areas of law implicate speech, broadly construed. Yet it became apparent after the study was underway that, while some findings appeared to be generalizable to both areas of law and for multiple industries, there may be some issues or nuances limited to either trademark or copyright law or to particular industries. Thus, more research on these themes is warranted.

57. The pioneering work in this field was conducted jointly by a famous legal academic, Karl Llewellyn, and a noted anthropologist, E. Adamson Hoebel. See K. N. LLEWELLYN \& E. adamson Hoebel, The CheyenNe Way: CONFlict and CaSe LaW IN PRIMITIVe JURISPRUDENCE (2002) (pioneering the study of the "trouble case" in disputing outside of formal legal system). For examples of anthropological studies building on the trouble case method in both developing and developed societies, see, for example, No ACCESS TO LAW: ALTERNATIVES TO THE AMERICAN JUDICIAL SYSTEM (Laura Nader ed., 1980); THE DiSPUTING PROCESS: LAW IN TEN SOCIETIES (Laura Nader \& Harry F. Todd, Jr. eds., 1978); Barbara Yngvesson \& Lynn Mather, Courts, Moots, and the Disputing Process, in EMPIRICAL THEORIES ABOUT CourTs 51 (Keith O. Boyum \& Lynn Mather eds., 1983).

58. See Carroll Seron \& Susan S. Silbey, Profession, Science, and Culture: An Emergent Canon of Law and Society Research, in THE BLACKWELl COMPANION TO LAW AND SOCIETY 30, 39 (Austin Sarat ed., 2004).

59. Id. 
understand how trademark and copyright disputes arise and are dealt with in the everyday practice of law.

\section{A. "Most Cases Settle": The IP Dispute Pyramid}

One of the most important features of the IP disputing landscape is that it takes place primarily outside of the formal legal system. ${ }^{60}$ Empirical scholarship on the disputing process in the United States indicates that most perceived grievances or injuries do not result in a formal dispute, and most disputes that arise are dealt with through informal processes such as negotiation rather than by means of adjudication in court. ${ }^{61}$

As discussed below, trademark and copyright claims that IP owners decide to enforce are most commonly resolved in a system of private negotiation outside of court-typically in negotiations begun after a demand letter (often called a "cease and desist" letter) is sent to an alleged infringer on the IP owner's behalf by a lawyer. This is true even for those disputes that result in formal legal proceedingstypically a lawsuit filed in court or in the Trademark Trial and Appeal Board ("TTAB"). ${ }^{62}$ Lawsuits to enforce IP claims are generally not a

60. For examples of studies of informal disputing processes, see Richard E. Miller \& Austin Sarat, Grievances, Claims, and Disputes: Assessing the Adversary Culture, 15 LAw \& SOC'y REV. 525 (1980-81). See also H. LAURENCE RosS, SETTLEd OUT OF COURT: THE SOCIAL Process of Insurance Claims Adjustments (1970); Stewart Macaulay, Non-Contractual Relations in Business: A Preliminary Study, 28 AM. Sociological ReV. 55, 61-62 (1963) (finding that even in the highly legalized relationship between automobile manufacturers and dealers, most disputes between these parties are dealt with by informal discussion or negotiation rather than by reference to the contracts that often control the issue in dispute or by initiating a lawsuit).

61. See, e.g., David M. Trubek, Joel B. Grossman, William L.F. Felstiner, Herbert M. KRITZER \& AUSTIN SARAT, CIVIL Litigation RESEARCH PROJECT FINAL Report S-75 to -76 (1983) [hereinafter CLRP] (reporting and analyzing the results of a nationwide survey of disputing behavior in both informal and formal legal settings in the United States).

62. Such suits are usually filed in federal court or the TTAB. Federal courts have exclusive jurisdiction to hear claims arising under the Copyright Act. 28 U.S.C. $§ 1338$ (a) (2006). Both federal and state courts have concurrent jurisdiction to hear trademark cases arising under the Trademark Act (Lanham Act). 15 U.S.C. $§ 1121$ (a) (2006); 28 U.S.C. § 1338(a). See also Duggan's Funeral Serv., Inc. v. Duggan's Serra Mortuary, Inc., 80 Cal. App. 4th 151, 157 58 (Cal. Ct. App. 2000) (holding that federal and state courts have concurrent jurisdiction over Lanham Act claims; ordering federally registered trademark cancelled due to fraud). Yet very few federal trademark cases are filed in state courts. The TTAB has jurisdiction to adjudicate disputes concerning the registrability of particular trademarks. 15 U.S.C. $\S 1067$ (a) (2006); see also Rosenruist-Gestao E Servicos LDA v. Virgin Enters. Ltd., 511 F.3d 437, 443-44 (4th Cir. 2007) (explaining that the TTAB is an administrative agency of limited jurisdiction, with statutory authority only to decide issues of trademark registrability). While there are other forums in the formal legal system where trademark and copyright enforcement claims may be 
large part of the day-to-day enforcement practices of trademark and copyright lawyers. Even filed lawsuits typically result in settlements well before trial. ${ }^{63}$ Furthermore, trademark and copyright lawsuits that are adjudicated to a resolution in federal court are statistically rare. ${ }^{64}$

As many of the lawyers in this study stated, "most cases settle." Indeed, when asked about their IP careers and practices, the lawyers for this study-who were generally very experienced and quite prominent in the IP field-indicated that they had little trial experience. Most of these lawyers identified "litigation" as one of their areas of practice. When probed as to what this meant, most of these lawyers stated that they filed proceedings before the TTAB or filed lawsuits in trademark and copyright cases and engaged in some pretrial discovery and motion practice in both forums. ${ }^{65}$ But very few had tried a trademark or copyright case to a judge or jury in their entire careers. ${ }^{66}$ Five of the study lawyers had tried at least two such cases in their careers. But most of the daily practices of these experienced IP lawyers did not involve court activity or other adjudication, but rather counseling and negotiation.

Thus, understanding enforcement of trademark and copyright claims requires understanding how those claims arise, become disputes, and result in settlements-mostly outside of (albeit

filed, such as the International Trade Commission (see 19 U.S.C. $\& 1337$ (2006)) or the U.S. Customs Service (see 15 U.S.C. $\S 1125$ (2006); 19 U.S.C. $\S 1526(\mathrm{a})$-(b) (2006)), these forums have limited and specialized jurisdictions and were not the focus of much discussion in the interviews completed for the present study. TTAB suits were discussed in some of the interviews, but most lawyers in this study referred to and used examples from their practice dealing with either demand ("cease and desist") letters or lawsuits filed in U.S. District courts.

63. See Landes, supra note 55, at 757-61.

64. See id. In this respect, IP law is no different from other contemporary areas of the civil justice system. The "disputing pyramid" accurately describes case dispositions in both civil and criminal cases in the United States. Most civil lawsuits settle out of court. See Marc Galanter, Reading the Landscape of Disputes: What We Know and Don't Know (And Think We Know) About Our Allegedly Contentious and Litigious Society, 31 UCLA L. REV. 4, 11-31 (1983) (surveying the empirical literature on civil disputing and litigation in the United States). Civil cases that result in final adjudications after a trial are also statistically rare-and becoming more so. See CLRP, supra note 61; see also Galanter, supra note 54 . The same is true in criminal cases, where most cases result in plea-bargains. See generally Albert W. Alschuler, Plea Bargaining and Its History, 79 COLUM. L. REV. 1 (1979).

65. It is not clear from this study how much the interviewed lawyers practiced in TTAB proceedings. All of them did to some extent, as counsel for either Plaintiff or Defendant. But most of the discussion and examples cited from the interviews concerned experience in federal court when discussing "litigation."

66. In part, this stems from the fact that some of these lawyers indicated they turn litigated cases over to colleagues if the case does not settle and therefore requires extensive discovery, hearings, or trial. 
influenced by) formal court proceedings and understandings of substantive IP law.

B. "Naming, Blaming, and Claiming": Mapping and

Understanding Trademark and Copyright Enforcement in IP Law's Shadow

This section draws on insights developed by Felstiner, Abel, and Sarat in their influential 1981 article "The Emergence and Transformation of Disputes: Naming, Blaming, Claiming . . . .,67 Their article provides a useful framework for analyzing disputing behavior in stages, especially the under-examined earlier stages of disputes that occur outside of formal legal institutions and are typically under the radar of both scholarly analysis and legal system scrutiny. "Naming" is the initial stage of a dispute. 69 This stage occurs when the victim becomes aware he has suffered an injury or violation of rights. ${ }^{70}$ The second stage of disputing is termed "blaming," where the victim assigns blame to a particular target for the harm he has suffered. ${ }^{71}$ The third stage is "claiming," in which the victim gives voice to the grievance and demands a remedy. ${ }^{72}$

The main contribution of the Felstiner et al. framework is to provide a way to describe and analyze process of how disputes emerge and how and why they develop through each stage. This framework also highlights the role of agents (such as lawyers), cultural factors (such as ideologies of rights), and even psychological factors (such as disputants' own sensibilities) in shaping the development of disputes.

The research interviews for the present study sought to understand how trademark and copyright owners became aware that their rights had been violated and the factors that influence whether and how those rights are enforced.

67. William L.F. Felstiner, Richard L. Abel \& Austin Sarat, The Emergence and Transformation of Disputes: Naming, Blaming, Claiming . . , 15 LAW \& SOC'Y REV. 631 (1980-81).

68. Id. Their article develops a useful typology of stages in the disputing process and focuses attention on the factors that shape a dispute at each stage and that transform a dispute from one stage to the next (or not).

69. Id. at 635 .

70. Id.

71. Id.

72. Id. at 635-36. 


\section{Identifying Potential Disputes ${ }^{73}$}

The lawyers in the present study identified several ways that their clients generally became aware of potential trademark or copyright infringement claims. The lawyers themselves sometimes became aware of potential claims somewhat serendipitously, although this was not typical. ${ }^{74}$ Some of the study lawyers stated they had paralegals monitor the Internet or use commercial trademark "watch" services to discover potential infringers for clients with large trademark portfolios. More frequently, the clients themselves identified potential claims. These clients learned of potential claims in various ways. Clients with large trademark portfolios often have inhouse staff monitor for infringement online. One example cited by a study attorney was a large client who dedicated several staff members to search the Internet for alleged trademark and copyright infringement. Several attorneys also gave as example situations wherein clients' sales staff became aware of potential infringements while attending industry trade shows or conferences, or from learning of instances of actual consumer confusion between their employer's and a competitor's products or services when dealing with customers.

While these examples demonstrate a number of ways for potential infringement claims to come to an IP owner's attentionwhich was the main impetus for asking this line of questions in the interviews-they also may demonstrate that many of the study lawyers' clients have fairly sensitive awareness of their IP rights and sometimes also have systematic approaches to self-policing. One theme suggested by this interview data is that different industries may develop their own norms, beliefs, and rules of thumb ${ }^{75}$ as to what their legitimate IP rights are and what constitutes infringement of those rights. ${ }^{76}$ Another theme from these interviews is that client

73. The interview questions for this section of the study aimed at understanding both the "naming" and "blaming" stages of trademark and copyright disputes. The focus was on how IP owners become aware their rights may have been violated and by whom.

74. For example, four lawyers in this study gave examples where their colleagues in other firms brought potential infringement claims to their attention. These examples all involved attorneys who represented very large trademark or copyright clients and whose colleagues knew this and who occasionally noticed something in the press, online, or in the industry that prompted them to contact the lawyers with this information.

75. Some recent scholarship develops similar ideas regarding industry norms or expectations of IP rights in particular industries. See, e.g., Dotan Oliar \& Christopher Sprigman, There's No Free Laugh (Anymore): The Emergence of Intellectual Property Norms and the Transformation of Stand-Up Comedy, 94 VA. L. RFV. 1787 (2008).

76. Two of the interviewed lawyers in this study worked for Hollywood movie studios 
awareness of the proper scope of IP rights may change over time. This theme was suggested by several lawyers who opined that certain clients "never used to care" (as one lawyer put it) about their IP assets, but had more recently become increasingly aware of the potential value of those rights, particularly when dealing with business competitors. ${ }^{77}$ While this theme was not fully probed in most of the interviews, it does highlight the fact that the process of "naming" and "blaming" can be significantly influenced by the IP owner's evolving understanding of the nature, scope, and value of trademarks and copyrights. The lawyer's role in shaping such client understandings of IP rights was less clear from the interviews. Most of the study lawyers described their roles in identifying potential disputes as either limited or indirect. The lawyers most often described that, typically, clients come across a potential infringement claim and contact the lawyer for advice. Of course, over time, lawyers may influence how clients perceive what their IP rights are and what constitutes a violation of those rights in the course of educating clients about which disputes are worth pursuing and which are not. This topic is the focus of the next section.

\section{Selecting IP Targets: When Is Enforcement "Worth It"? ${ }^{78}$}

A major part of the study interviews focused on understanding how lawyers advise clients regarding whether a potential trademark or copyright infringement case merits enforcement efforts, or, as one lawyer put it, "is it worth it to go after this guy?" All of the lawyers agreed that it does not make sense from a legal or business standpoint to attempt to assert every potential trademark or copyright claim. Thus, a central part of the questioning on this topic probed the factors

(one in-house, one outside counsel). Both of these lawyers stated that the movie industry had particular norms and "rules of thumb" concerning what is permissible use of trademark and copyright protected works. However, the research interviews were not designed to necessarily elicit industry-specific information, which is why I consider this theme suggestive when compared with other more prominent and thoroughly probed themes from this research.

77. See, e.g., KeVIN G. RIVEtTe \& David KLINE, Rembrandts IN THE AtTic: Unlocking the Hidden VAlue of Patents (2000) (discussing the need for companies to understand the potential economic and business value in company-owned intellectual property).

78. The interview questions for this section aimed to understand "claiming" behavior in trademark and copyright disputing. More particularly, what factors are relevant to determine whether a potential claim is important enough to take steps to enforce IP rights and, once the decision to enforce has been made, what factors influence how-and how aggressively-to enforce them. 
that influence the decision to enforce a claim. The interviewed lawyers identified both legal and non-legal factors. The legal factors go directly to the merits of the case: does the IP owner have strong legal rights to pursue an infringement claim? The lawyers also identified various non-legal factors relevant to the determination of whether or not to assert any particular claim.

\section{a. Legal Merits of Claim}

Perhaps not surprisingly, all of the interviewed lawyers identified the legal merits of a case as an important factor in determining whether a particular enforcement effort was "worth it." Even though most trademark and copyright disputes are dealt with primarily in private negotiation rather than adjudication in court, the present research indicates that potential disputes are typically evaluated for legal merit and claims evaluated in terms of their likely success at trial. Private IP disputing thus truly takes place in the "shadow" of IP law. ${ }^{80}$ The lawyers' pre-enforcement legal analysis varied. When referring to trademark claims, most of the interviewed lawyers made reference to the Ninth Circuit "Sleekcraft" factors that are relevant to establishing a prima facie case for trademark infringement. ${ }^{81}$ As one lawyer explained:

A: For a trademark case, I pretty much go to Sleekcraft.

Q: What do you ... what does that mean?

A: The Sleekcraft case here in the Ninth Circuit. It sets forth the factors you need to analyze for likelihood of confusion, and I go through them automatically when I determine whether a case is worth it for the client.

Q: And likelihood of confusion...

A: Yes, the factors for infringement.

Q: So, what exactly do you do? How do you go through them?

A:I look at each factor, I figure out how it applies. How close are

79. All of the lawyers also stated that it was not possible to enforce trademarks or copyrights against all potential infringers, so a large part of their advice to clients was focused on determining which potential enforcement efforts took priority over others.

80. See Mnookin \& Kornhauser, supra note 10.

81. See AMF, Inc. v. Sleekcraft Boats, 599 F.2d 341 (9th Cir. 1979). In contrast, other federal circuits have their own list of factors, which are generally quite similar to those of the 9 th Circuit. See, e.g., Beebe, supra note 14. 
the goods, how close are the marks? Is this an intentional rip-off of my client's goodwill, and so forth? I go through them all and have a decent sense of how the case would look to a judge. That's . . . what my client wants to know, how good is this case if we go to court?

Q: Do you look at anything else? Anything on legal merits?

A: Sleekcraft and priority. I make sure the client has priority of rights in the mark.

Q: Can you explain priority a little?

A: Yes, sure, who is using the mark first. I don't want to make a claim and tell them there's likelihood of confusion and find they were using first. I've just admitted my client infringes (laughing). ${ }^{82}$

Several lawyers also responded that in addition to the factors relevant to the prima facie case, they routinely assess whether a potential target has any obvious defenses to a trademark infringement claim. When pressed for an example from a recent case, these lawyers most often mentioned "parody" examples. As one lawyer explained:

A: Parody. I always tell my client not to make a claim in a parody case. It's not worth it.

Q: Why not?

A:Messy. You're not going to win, and it's a lot of publicity sometimes, makes the newspapers. Ignore them and they will just go away. If you persist, you lose your case and get in F.3d. ${ }^{83}$

The lawyers' descriptions of their method for analyzing the legal merits of a copyright case were similarly focused on elements of proof for copyright infringement, albeit mostly described in simplified form. ${ }^{84}$ Many of the interviewed lawyers also indicated that in most cases their assessment of how meritorious an infringement claim might be against a potential copyright or trademark target was generally fairly easy. Some lawyers stated that they knew a good or bad infringement case on the merits "pretty quickly," in most cases.

82. All of the quotes in this study are verbatim statements made in the research interviews. " $A$ " indicates the interviewed lawyer's statements. "Q" indicates the interviewer questions.

83. See supra text accompanying note 82 .

84. See, e.g., Feist Publ'ns, Inc. v. Rural Tel. Serv. Co., Inc., 499 U.S. 340, 361 (1991) (the elements of copyright infringement claim include "(1) ownership of a valid copyright, and (2) copying of constituent elements of the work that are original."). 
One lawyer put it as follows:

A: I look at whether it's a copy. Is it just copying my client? Is it too close?

Q: As opposed to what, what would not be just a copy?

A: Something that shows originality, it's not too close. But you know when they copied you, if it's a real copy. That usually jumps out at you.

Q: What types of copyrights or things are you talking about?

A:Different types, clothing designs, gaming-I do a lot of copyright work for a gaming company-a popular cartoon character, a mix.

Q: So, can you tell that it's a copy or not ... likely to be an infringement or not just by looking or what else do you do?

A: You can tell pretty easily, is it a copy. ${ }^{85}$

Even if these lawyers often characterized their legal assessments as relatively straightforward, they also frequently qualified this. As a number of lawyers indicated, their assessment of potential enforcement claims also reflects awareness of the uncertainty of legal outcomes in the real world. As one lawyer stated:

A: Of course, if you ever do get before a judge or jury, your own sense of what's a likely outcome in a case can go out the window. There's a lot more uncertainty. Judges don't always get it right, so you have to factor that into it for the client. ${ }^{86}$

In a recent article, legal scholar Leah Chan Grinvald suggests that companies and lawyers who send aggressive demand letters in trademark disputes appear not to have conducted much legal investigation as to the legal merits of some of their claims. ${ }^{87}$ But the present study suggests that the issue may be very different. All of the study lawyers conduct some investigation as to the legal merits of every claim, and it appears from the interviews that the clients do as well. The lawyers in this study stated that many if not most of their trademark and copyright enforcements dealt with facts that were relatively straightforward to analyze legally. The more challenging

85. See supra text accompanying note 82 .

86. Id.

87. See Grinvald, supra note 4, at 643-45 (suggesting that corporate trademark owners act unreasonably when they fail to adequately assess the relevant facts and legal merits of a claim). 
issues according to the interviewed lawyers related to whether it was "worth it" to enforce a potential claim based on non-legal factors. As I argue below, ${ }^{88}$ lawyers and their clients often knowingly assert weak trademark and copyright claims, but it is not because they are unaware those claims may lack merit. As my interview data suggest, it is because, under some circumstances, asserting even weak claims can be quite effective for the trademark and copyright owners.

\section{b. Non-Legal Factors}

\section{i. Enforcement Costs}

In addition to assessing the legal merits of a potential claim, all of the interviewed lawyers also identified the additional non-legal factors that significantly shaped their advice to clients and the clients' willingness to commence a claim against a potential enforcement target. Chief among these factors was cost. ${ }^{89}$ All of the lawyers stated that the likely costs of enforcement strongly shaped both their legal advice and the clients' willingness to initiate a claim to enforce their copyright or trademark rights ${ }^{90}$ :

Q:Can you tell me what factors other than law are important in giving advice to a client about whether it makes sense to bring a claim?

A: First: cost, second: cost, third: cost.

Q:I'm tempted to ask what's fourth.

A: Maybe not cost, but it comes close.

88. See infra Part IV.

89. The interviews for this Article were conducted over a several-year period both prior to and after the 2008 economic recession began. Thus, the finding that costs were a major factor in determining whether to initiate an infringement dispute is not a simple function of the effects of the recession on lawyers and their clients, although the post-2008 interviews made it clear that the costs of IP enforcement were perhaps an even more critical factor in challenging economic times.

90. The American Intellectual Property Association (AIPLA) publishes annual survey data from its members estimating the typical costs of litigation in trademark and copyright cases. The median estimated costs for litigated trademark and copyright cases in the AIPLA 2011 survey range between $\$ 200,000$ to more than $\$ 1$ million for cases litigated through the end of pretrial discovery and to completion. See Steven M. Auvil \& David A. Divine, Am. INTELL. PROP. L. ASS'N, REPORT OF THE ECONOMIC SURVEY 35 (2011). The estimated amount varies according to the estimated amount at risk in the litigation. But the salient point from this data is that IP practitioners report that litigation costs associated with trademark and copyright litigation may be significant. 
Q: Is that for every client or do you mean for the smaller ones?

A: I don't know of a trademark or copyright client who is not extremely sensitive to enforcement costs. I have small client companies and Fortune 100 company clients. It's a big deal to all of them. ${ }^{91}$

\section{ii. The Importance of the IP at Stake}

Another critical enforcement factor identified by almost all of the interviewed lawyers was the importance of the particular IP to the client. As these lawyers explained, enforcement efforts were much more likely to be undertaken against potential targets when the alleged infringement involved the client's "core" IP, or "crown jewels," as several lawyers put it. ${ }^{92}$ One trademark lawyer working inhouse for a Fortune 100 food products company explained:

A: It's too expensive to protect everything. We have a hierarchy of brand protection. First, protect the house brands that we use again and again. We have a family of related brands, so we enforce these aggressively. Next, our best-sellers. We have a few brands that have a long history of sales and goodwill-this is the stuff people know us for. We'll do anything to protect these. ${ }^{93}$

\section{iii. Targeting Competitors}

Second to cost, the interviewed lawyers most often identified target characteristics as highly influential in enforcement decisions. Both the lawyers and their clients stated that enforcing rights against a competitor was a high priority in most circumstances. ${ }^{94}$ As one lawyer stated:

A: It makes a big difference if it's a competitor, if the infringer is a competitor of my client.

Q: Any client?
A: Most.
Q: Why is that?

91. See supra text accompanying note 82 .

92. See Christopher Buccafusco \& Christopher Sprigman, Valuing Intellectual Property: An Experiment, 96 CORNELL L. REV. 1 (2010).

93. See supra text accompanying note 82 .

94. As discussed below in Part IV, this is often true even when the lawyers and clients are aware that the legal merits of enforcement are weak. 
A: Well, two things at least. Pisses them off. They're trying to take advantage of your client by using their mark or copying. And it is unfair, it's unfair competition. So both. ${ }^{95}$

Another lawyer elaborated on this theme as follows:

A:Obviously, yes, it's really important to go, to enforce these [trademarks and copyrights] when it's a competitor.

Q: May be obvious, but tell me why. I'd like to know why. It's not obvious to me.

A:In the trademark example I told you about, it's a direct competitor, so the goods and services are too close. You have to go after that. Also, some clients just want to make it difficult for the competition. If they are using some of your property, your intellectual property, go after them. Make them pay. Make them spend money if they want to do that.

Q: Like get a license?

A: No, I mean make them stop and make them pay for litigation if they don't. We can beat them up in the market and beat them up in court, too. Makes them think twice next time. Makes them disrupt things to deal with us.

Q: Well is that a goal? Use the IP to get them to, to disrupt their business, is that what you're saying?

A: Yes, sometimes. Also, raise the costs of them competing with us.

$\mathrm{Q}$ : Where is that coming from? Is that your goal?

A: The client's.

Q: How many? I mean how typical is this attitude?

A: I would say it's pretty common among my clients. ${ }^{96}$

This theme was prominent in the interviews. Many of the lawyers made it clear that clients generally want to enforce their IP rights aggressively against competitors. Indeed, that is often one of the motivating factors to get strong trademarks and copyrights: the ability to enforce those rights against competitors in order to gain a competitive advantage in the marketplace.

95. See supra text accompanying note 82 .

96. See supra text accompanying note 82 . 


\section{iv. Target Size and Sophistication}

Potential target size and sophistication also influences the decision to enforce IP rights. All of the interviewed lawyers were asked whether they considered the target's size a relevant factor in determining whether to initiate enforcement steps. The answer was resoundingly "yes." But size matters in different ways. When probed, the attorneys explained that they were well aware that asserting claims against a smaller company was often easier than targeting a larger company. The lawyers stated that smaller companies generally could not effectively resist a trademark or copyright claim or threatened lawsuit due to the high cost of IP legal proceedings, regardless of the legal sophistication of the target or their lawyers. Target "size" as used by the interviewed lawyers is thus most often a proxy for the ability to afford to defend against an asserted IP claim. This was a prominent theme in many of the interviews that is reflected in the discussion below:

Q: Why go after the little guy?

A:Ease. It's easy often. They may not have in-house or any lawyers to help. They may be intimidated. You can often get them to roll over with a few threats and some sweet talk.

Q:Like what? What does that mean "threats and sweet talk"?

A:Threats means we'll sue your sorry little company if you don't stop.

Q: So you can bully them, the little ones? Do they capitulate?

A: Yes. Sometimes. They may just stop or they may take you seriously at least and respond. That makes it easier to get something settled.

Q: What's sweet talk?

A: Scare them with your big guns, then let them know you're willing to be reasonable. They aren't going to win, but you won't be an ass about it if they negotiate reasonably with you to stop on reasonable terms. ${ }^{97}$

On the other hand, many of the lawyers in the interviews expressed a belief that working with a target that was sophisticated or which had experienced IP counsel also had advantages. Under these

97. Id. 
circumstances, the lawyers suggested, opposing counsel were often able to efficiently come to settlement terms precisely because both sides had a realistic sense of the legal merits of the claim and some idea as to what the "right" resolution was likely to be.

\section{v. Unflattering or Disparaging Use}

Another enforcement factor that was discussed by some of the lawyers was whether the potential infringement was unflattering or disparaging. Although this factor was not raised often in the interviews, it was cited frequently enough to demonstrate that at least some of the interviewed lawyers' clients had a highly protective attitude towards their IP and the company image and goodwill behind it. These clients were sometimes quite sensitive to what they perceived to be uses of their IP that created some sort of negative association. One lawyer who represented a large corporate client with copyright and trademark-protected (and very cute) animal characters that were used to promote children's merchandise stated that it was imperative for his client to police against unauthorized uses of this character that appeared to be unwholesome or even unflattering. He provided examples of enforcement efforts against targets that made non-commercial online use of the characters in sexually suggestive situations. Other examples included the use of a look-alike character on tee-shirts depicting the animal shooting guns or smoking marijuana. The lawyer's self-described "marching orders" were to routinely do everything possible to stop these depictions of the IPprotected characters on the theory that the unauthorized uses tarnished the goodwill associated with them.

A second lawyer, however, stated that he advised clients "never" to enforce trademark rights against a "parody" use of its mark. When asked why he explained:

A: You can't win. You sue and the whole thing is now even more public. The parody is more well known. Half the time, no one saw the parody other than the client. You go forward and you get a published F.3d case that says the parody is perfectly lawful and your client and its trademark look silly. ${ }^{98}$

\section{vi. Client Culture}

The research interviews revealed, in a number of ways, that the

98. See supra text accompanying note 82 . 
decision to assert IP claims is not entirely a rational decision. ${ }^{99}$ Many times, the interviewed lawyers identified client-specific characteristics that were relevant to enforcement decisions. One significant factor was whether the client was an "aggressive" enforcer of its IP rights. All of the lawyers agreed that certain of their clients had a company culture of aggressive trademark or copyright enforcement, which often shaped how the lawyers provided legal advice. Generally, the lawyers explained, the more aggressive the client, the more amenable the lawyer would be to "push the envelope" in enforcing rights. Two lawyers provided examples where a particularly aggressive IP enforcement client's trademark had been selected by the company's CEO. Because of that, both the clients and the lawyers understood that aggressive enforcement efforts were expected. On the other hand, a number of lawyers made it clear that they had certain clients who were very sensitive to potential negative publicity that might ensue from aggressive IP enforcement. For these clients, the lawyers stated, it made more sense to avoid enforcing claims that may appear to be weak. There is thus variation in enforcement practices based not simply on the legal merits but also on the variable of client culture, particularly the issue of how sensitive the IP client is to public opinion and company image.

In sum, the present research shows that law clearly matters for both IP lawyers and their clients in deciding whether and against whom to assert trademark or copyrights- - but only to a certain extent. Other factors are important as well and may greatly influence the decision to assert rights. Trademark and copyright owners are often much more likely to attempt to enforce their IP rights when the alleged infringer is a competitor. In that circumstance, the IP rights are sometimes asserted as a means to gain competitive advantage in the marketplace rather than merely to vindicate legal rights. In contrast, enforcement is generally less likely when the potential target has some non-competitive relationship with the trademark or copyright owner. The examples that were most often cited included targets who were customers or distributors of the IP owner. The two movie studio in-house IP lawyers interviewed for this study specifically stated that enforcing rights against fans, who are typically

99. Buccafusco \& Sprigman, supra note 92, at 44. Buccafusco and Sprigman argue, based on experimental data, that IP owners may routinely overvalue the value of their intellectual property. One suggestion from this study is that IP owners may not evaluate the "worth" of their legal claims entirely rationally. 
also customers, is not something that they or their clients like to do. Both lawyers provided examples of how their movie studios monitored online fan sites that contained copyrighted movie clips or characters. These lawyers explained their "rule of thumb" in determining whether to take enforcement efforts against fan sites similarly: as long as the alleged infringement did not appear to be an attempt to "commercialize" their clients' IP or to disparage the movie or characters, the lawyers indicated they would be less likely to assert copyright claims. In these circumstances, the fan's use of the copyrighted material was deemed non-threatening and likely to generate good publicity and goodwill towards the copyrighted work and the client.

\section{CEASE AND DESIST: ARE IP RIGHTS OVER-ENFORCED?}

One goal in the present research is to understand whether trademark and copyright claims are "over-enforced" in everyday practice and, if so, to also understand the lawyer's role in this process. Because of this, a great deal of questioning in the research interviews focused on this theme. "Over-enforcement" is an imprecise and somewhat pejorative term, and it was purposely not defined in the interviews, unless the lawyers themselves provided a definition. The reason for this was to elicit the lawyers' own views, understandings, and assessments of enforcement efforts and tactics, including their characterizations of the proper limits of IP enforcement. A major theme discussed below is whether lawyers in fact help clients enforce trademarks and copyrights against alleged infringers when the lawyers themselves believe the legal merits of the claim are weak. ${ }^{100}$

\section{A. Demand Letter Lawyering}

This section explores the logic and tactics of demand letter lawyering in the disputing process. The first step in enforcing most

100. There is a growing awareness that trademark and copyright owners may routinely and aggressively assert weak claims. See, e.g., Grinvald, supra note 4, at 628-29, 643; see also JoHN TEHRANIAN, INFRINGEMENT NATION: COPYRIGHT 2.0 AND YOU (2011) (describing examples of over-enforcement by copyright owners); Cotter, supra note 6, at 1273 (developing theoretical model that explains how and why fair use defense to copyright infringement claims may be underused and thereby allows for over-enforcement of copyrights); K.J. Greene, Abusive Trademark Litigation and the Incredible Shrinking Confusion Doctrine-Trademark Abuse in the Context of Entertainment Media and Cyberspace, 27 HARV. J.L. \& PUB. POL'Y 609, 612-14 (2004); Port, supra note 14, at 589. But there is little systematic empirical examination of how these practices play out in everyday legal practice. 
trademark and copyright claims is to contact the target, assert those claims, and make a demand. ${ }^{101}$ All of the interviewed lawyers identified "cease and desist" letters as an important tool in their enforcement practices. ${ }^{102}$ These letters were described as the "opening salvo" that both begins the disputing process and sets the tone for the anticipated ensuing negotiations in almost all cases. This process is typically conducted primarily by letter and telephone, and most of the lawyers expect that almost all of these disputes will result in a negotiated settlement. As one lawyer explained:

A: The vast majority of disputes are resolved in "cease and desist" letters. It's often relatively clear who's going to win and litigation is so horrifically expensive-particularly with copyright, which has a fee-shifting statute, if you lose you have to pay the opposing party's attorney fees, usually-so cases settle. So it's a process of exchanging letters, phone calls, emails, and the process ends in settlement. ${ }^{103}$

When discussing what makes a "good" demand letter, the lawyers often agreed among themselves: good letters were serious, identified the client's rights forcefully and clearly, specified how the target infringed those rights, and made some demand to cease infringing activity. The main goal of most demand letters, the lawyers explained, is to put the target on notice of the IP owner's claims and to initiate negotiations to resolve the matter. The tone of the letter was often described as particularly important. As the lawyers explained, a letter needs to convey that there is a serious dispute so that the target does not ignore or downplay the matter. By making a demandwhether to cease an infringing use altogether, modify a trademark, take a license, or some other remedy-the letter at least implicitly threatens to take further legal steps if no solution can be negotiated.

101. Precisely because much of trademark and copyright disputing involves private negotiations under the radar of the formal legal system, there are no reliable statistics that indicate what percentage of enforcement claims occur outside of court. But the present study suggests that the vast majority of such claims are handled by means of informal negotiation. The lawyers interviewed for this study indicated that almost all of their enforcement efforts began by contacting a target by means of a letter or phone call from either the client or attorney.

102. For a good, albeit non-scientific, study discussing aggressive cease-and-desist letters,

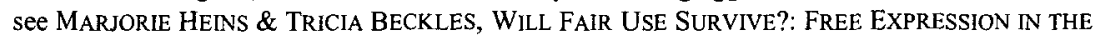
AGE OF COPYRIGHT CONTROL 29-36 (2005) (examining letters from actual disputes archived in the Chilling Effects Clearinghouse database). There is a chilling effects database online. See Chilling Effects, CHILLING EFFECTS CLEARINGHOUSE, http://www.chillingeffects.org (last visited Feb. 11, 2012).

103. See supra text accompanying note 82 . 
Sometimes, the interviewed lawyers explained, a demand letter expressly states that further legal action may be undertaken if a resolution is not achieved. One lawyer explained that the demand letter needs to convey that further (and expensive) legal action will ensue unless there is an acceptable settlement, even if the IP owner has little or no intention of taking further action in many cases. This lawyer (and others) characterized the demand letter and negotiation process as a game of "bluffing it":

A: It's kind of like a combination of poker and chess. It has a lot to do with the rules, with the law, but then it gets to the point where it's kind of bluff and counter-bluff. So the value of any case is the strength of the merits of the case-how the courts would decide it - times how much it's going to cost to achieve that result times the perception of the other party that you're prepared to go forward and achieve that. So, even if you have a good case and a lot of money, if they know you're bluffing, they'll tell you to forget about it. The letter has to say to them, "hey, I'm serious, I'm not bluffing," even if you are. ${ }^{104}$

How forcefully to threaten potential litigation in a letter is a question that arises on a case-by-case basis. It varies depending on who the target is (e.g., a competitor or not) and how important or willful the alleged infringement is perceived to be. There is also some risk in sending a demand letter because it can induce a target to file its own declaratory judgment lawsuit in a possibly inconvenient forum for the IP owner.

When asked whether very "aggressive" demand letters are effective, most of the interviewed lawyers responded that, while they sometime can be, overly aggressive letters can also backfire. One lawyer characterized such examples as:

A: Look, the one time you assume an over the top letter will scare the infringer into compliance or capitulation, you won't get it. They'll ignore you or, worse, dig in their heels even if they might otherwise negotiate or give up, just because you made them angry. Or they'll have a cousin who's a lawyer and get free legal counsel because you got them angry. ${ }^{105}$

Thus, the demand letter is often the opening salvo to a negotiated settlement. The letter can set the tone for making settlement more or less likely. The lawyers described an effective letter as one that

104. Id.

105. Id. 
sufficiently informed the target as to the legal risks involved in continuing its alleged infringing activities, while at the same time leaving room open for discussion. This last part was important to many of the lawyers. They stressed that overly aggressive letters or ones that made over-broad legal claims can undermine the lawyer's credibility in any ensuing negotiations, particularly if the target obtains experienced trademark or copyright legal counsel. According to one of the lawyers:

A:You'll look foolish. Especially if the lawyer on the other side is experienced. I mean someone who knows trademark law, not one of those patent lawyers who dabbles in trademark. Someone who knows the nuances. It can be a small community. We all know each other sometimes, know the other guy's reputation. And we all know the law. So sometimes the easiest case is to write a letter to let the trademark lawyer on the other side know your client's serious. Then we both know about what the settlement should be and it gets done without too much cost to both clients. ${ }^{106}$

One further tactic identified by a number of the interviewed lawyers is to draft a complaint for trademark or copyright infringement and send it to the target with the demand letter. The obvious message such a tactic conveys is that the alleged infringement is a serious matter that will result in expensive litigation if the matter is not resolved. Some lawyers explained that they had several options after drafting a complaint. One is to send the complaint to the target but not file it with the court or formally serve it. This option is not ideal, the lawyers explained, because it does not preserve the IP owner's right as the first-filer in a lawsuit to select the court for any litigation that may ensue and thus possibly obtain some advantage. A second option described is to file the complaint, but not serve it. This allows the IP owner to select a desired litigation forum and to communicate the seriousness of the matter, while still sending a message that the plaintiff is willing to negotiate. Most of the lawyers stated that drafting complaints was generally reserved for more serious matters that warranted having the client spend the money. Almost all of the interviewed lawyers opined that sending a complaint with a demand letter very frequently helped resolve these serious matters. One lawyer explained:

A: It can have in terrorem effect. You can't ignore it. The infringer will take it seriously because he realizes he needs to get a lawyer

106. Id. 
right away. And once he realizes he may have to spend a billing cycle or two resolving this if it doesn't go away quickly, he will come to the table and settle. ${ }^{107}$

\section{B. Trademark and Copyright Bullies}

Even if the interviewed lawyers frequently stressed the need for balance and not making outrageous or over-reaching legal claims, they all admitted that sometimes "aggressive" or "bullying" tactics can be quite effective. ${ }^{108} \mathrm{~A}$ very aggressive demand letter, many explained, can coerce a target to capitulate and to cease infringing activity immediately-what one lawyer termed a "slam dunk." When discussing this topic, many of the lawyers provided examples of companies, and sometimes law firms, that they believed engaged in "bully" trademark or copyright enforcement. In fact, three of the same companies and two law firms were identified as bullies by about a third of the interviewed lawyers. ${ }^{109}$ Revealingly, the lawyers were loath to self-identify as bullies but did admit that they sometimes engaged in aggressive enforcement tactics, most often identified as sending demand letters that over-stated their client's rights or potential remedies, sending a complaint, and taking very aggressive and unyielding positions in negotiations. When asked whether they had ever enforced trademark or copyright claims the lawyers believed were weak, many of the interviewed lawyers responded that they had. The interviews probed specific examples:

Q: How does that work if you have a weak case on the merits?

A: So, even if you have a weak case, if you have a lot of money, if the client is willing to spend the money, and for some reason they're afraid of you, so you'll win, even if you don't have a good case on the merits.

Q: What makes them afraid of you? Can you give me an example?

A: Size, resources. Sometimes a reputation that your client will take a case to court.

Q: Has that happened in a recent trademark case for you, where you represent a big client and are trying to enforce a weak case on

107. Id.

108. On the topic of IP "bullies" generally, see sources cited supra note 29.

109. It was also somewhat humorous that the bully lawyers were sometimes identified by geographical region. A typical example provided was "New York" or "Los Angeles" lawyers. 
the merits, weak in your opinion?

A: Oh yeah! (laughs) I've had a case recently where I think we were probably wrong on the merits. But the client wanted to pursue this company for infringing its trademark. The lawyer on the other side was yelling at me about we didn't have a case, and I said you must be confusing me with somebody who cares about the merits. We are the giant in this case and we've decided we're not going to tolerate this, we're not going to give up.

Q: Was that effective?

A: Yeah, it worked. They gave up. We just didn't want this individual using the client's mark. They're no threat to us, a different world, very different services. No real likelihood of confusion. But we just didn't want them to use it, use their mark. In that case it was a dilution analysis. We didn't want a lot of people using our mark, even if they use it in a very different field.

Q: Was that an actual dilution claim, a claim under the Lanham [Act] dilution statute?

A: No, just a straightforward trademark infringement claim.

Q: Was that your idea or the client's to go after this company, even though you thought the claim was weak? Let me clarify, too, did you tell the client you thought the claim was weak?

A: Yes, the claim was not particularly meritorious. I told the client that. But we decided any time we'd try to enforce the mark the other side would come back with a list of registrations or uses and tell us it's not as strong as we think it is. So we're going to stop each case. It's expensive.

Q: Is that part of the strategy, is making it expensive for the other guy something you think helps your client get its way?

A: Usually, plus they know my client is in court every day and will pay to litigate. You've got to be willing-if it makes sense--to spend a few tens of thousands of dollars, litigate it for a while. At that point, the little guy will give up because he's convinced we have the will to go through with this. We sent some motions, interrogatories, depo notices, make him go through some billing cycles with his attorney and they have to give up. ${ }^{110}$

Another lawyer similarly explained:

110. See supra text accompanying note 82 . 
A: Why assert a weak claim? (laughs) It works. It sometimes works.

Q: How? You say it works, tell me how.

A:You'd maybe be surprised how often people, not just individuals, but companies, even bigger ones, don't want to deal with this. If you show them your client is willing to litigate this if need be, they don't want to spend the money to call your bluff. Small companies can almost never afford to resist a really aggressive client. That's, again, that's why I told you a reputation for being aggressive can help. Nobody thinks [company name] is afraid to sue you, so better to settle: ${ }^{11 \mathrm{I}}$

The interviewed lawyers provided a number of examples where they believed they had been able to successfully assert weak trademark or copyright claims against a target. Often these instances involved targets who were individuals or relatively small companies. Perhaps the most over-the-top example involved an 11 -year old girl who (with her parents) operated a very small web-based doll business that allegedly used an infringing trademark of a large high-tech company. This lawyer admitted that the legal claims against the girl and her family were "probably pretty weak," but insisted that there was nothing improper in sending a very strong demand letter that threatened litigation if the allegedly infringing trademark was not immediately removed from the site (it was). This same lawyer identified another client company that had been taking an extremely aggressive stance and filed lawsuits in many trademark enforcement actions. The company also used a tactic of getting targets to agree to enter stipulated judgments in court that contained self-serving statements about the plaintiff's valuable trademark and the amount of damages caused by the alleged infringement. The lawyer explained that the courts sometimes entered the stipulated judgments as-is, providing the trademark owner with a court judgment that could be shown to future enforcement targets to help persuade them to capitulate.

As some of the interview testimony indicates, aggressive and bullying enforcement tactics can work and are sometimes part of the IP owner's overall enforcement strategy. They are effective, in part, because many targets do not have the resources to defend a trademark or copyright claim on the legal merits in court. Even if they have such 
resources, they often choose not to spend those defending threatened or actual lawsuits. Moreover, as explained by the interviewed lawyers, trademark and copyright infringement cases tried in court can involve highly fact-specific and somewhat subjective analysis, and legal defenses are not particularly clear or consistently upheld. Targets, therefore, often acquiesce to enforcement demands because of the legal uncertainty that IP litigation entails. What this also suggests is that such practices, even if they do not occur in the majority of enforcements, can have a significant chilling effect on free speech and harm competition, as many IP scholars assert. ${ }^{112}$

\section{Lawyer Ethical Decision Making: Justifying Enforcement of Weak IP Claims}

Aggressive trademark and copyright enforcement can sometimes be very effective, according to the interviewed lawyers. But does aggressive enforcement raise any ethical concerns? A number of the interviews addressed this issue extensively. The questioning on this topic typically opened with a discussion of whether a particular enforcement effort or tactic that had been described had been "proper." Sometimes the question was framed as to whether it had been "ethical." Either way, the interviewed lawyers had ready justifications for enforcing even admittedly weak IP claims on behalf of clients:

Q: Now let me ask if you ever have any problem with that, with trying to enforce a client's weak trademark or copyright case? Did that bother you at all in this case?

A: No, I thought the case was weak, but not impossible. Your duty as a lawyer is not to do what's morally right, but to represent your client as long as you don't do anything that's morally wrong, and it's up to the court to decide what is right.

$\mathrm{Q}$ : And "beating up" on the little guy over a weak trademark claim is, as you say, not ethically wrong?

A: It raises the point of whether making the assertions of a trademark claim where you know they're not valid, is ethically wrong. But it's arguable. And it's for the court to decide, to say it's not valid, that nobody's going to be confused. So I think it's not

112. See, e.g., sources cited supra note 6. 
wrong. ${ }^{113}$

Another lawyer discussed these issues as follows:

Q: Ever advise a client not to pursue a target because the case was weak in your analysis, but the client says I want to go ahead against this guy?

A: Yes, sure.

Q: When's the last time you did that?

A: Earlier this year.

Q: What happened?

A: The case was marginal. Copyright case. The client knew it. But the motivation was reputational. Reputation in the industry. They just wanted to be known as a strong and aggressive defender of their IP rights.

Q: How was the case marginal?

A: My own analysis was that they copied, the other side, but they really copied the ideas, it's a different expression of the same idea. And assuming the judge gets it right, which you never know in a case like this, so 1 think we lose. And I warned the client. I don't want them to pay all this money and lose and blame me. And I want, too, from their perspective, to make good choices. I want them to go into it with their eyes open. I don't want them to believe their own press. I write these letters saying this is a clear infringement. I tell the client, between you and me, we know it's probably not a good case.

Q: Were you okay with enforcing that weak ... that nonmeritorious claim?

A: Yes. It was weak, but you never know. It's not going to be decided by a judge quickly.

Q: What happened in that case?

A: We got them to stop. The case settled when we filed a lawsuit in California.

Q: Have you ever told a client who was trying to enforce a weak case, a case you thought was not strong on the legal merits, you

113. See supra text accompanying note 82 . 
wouldn't do it?

A: I'm not going to pursue a case I'm uncomfortable with. I'd fire a client who insisted on an enforcement where I don't think it's right.

Q: Have you ever done that? How many clients have you fired for that?

A: I'm not thinking of any right now. ${ }^{114}$

This last theme arose strikingly in four of the interviews. In these four interviews, the lawyers each made some statement about how they would "fire" a client who asked them to enforce an IP claim where the lawyer believed the claim was without merit. When probed as to whether they had ever had a client who asked them to enforce a claim the lawyer had explained was weak or non-meritorious, these lawyers stated that they had. When asked about the specific instances, all four lawyers indicated that they followed the clients' instructions to enforce the claims. None of these lawyers could identify an instance where they had actually "fired" a client under such circumstances. At one level, this is perhaps not surprising. Perhaps the lawyers were pontificating and speaking in generalities when discussing their attitudes and what they "would" do under such circumstances. But when focusing on what they actually did in a particular case, the story became more complicated. Nevertheless, these four lawyers, and most of the rest of the interviewed lawyers, had little difficulty justifying using aggressive enforcement tactics in particular cases. They justified such tactics in three main ways: the need to "police" IP, the need to protect IP as "property," and the duty to represent client interests zealously.

\section{Policing IP}

The interviewed lawyers often cited a need to "police" their clients' trademarks and copyrights. They explained that the failure to do so on any particular occasion could lead to difficulties in enforcing rights against other targets in the future. These lawyers most often used this justification when referring specifically to trademark examples, and there is a body of law that suggests trademark rights can be diminished or lost due to the owner's failure to police third party uses of the mark (although it is far from clear what level of

114. Id. 
policing might be required). ${ }^{115}$ Yet the interviewed lawyers sometimes also used this justification when referring to copyright enforcement examples, even though there is no comparable duty to police in copyright law. ${ }^{116}$

\section{IP as Property}

The lawyers also relied on property metaphors when explaining why they believed vigorous IP enforcement efforts were sometimes justified. When referring to trademark examples, the most frequently used phrases included the "need to build a fence around" their client's trademark, or to "wall off" and protect a mark in order to keep it distinct in the marketplace. Several lawyers stated that they needed to protect the IP from "dilution" even when they were not referring to a formal trademark dilution claim. When referring to copyrights, a number of the interviewed lawyers stressed their belief that vigorously enforcing copyrights was justified by the very fact of copying by another, often suggesting in conclusory fashion that any unauthorized and substantial copying of protected work was inherently "bad" or unlawful "free-riding." Several lawyers characterized unauthorized copying as "theft" of property. One lawyer explained that copyrighted work was "their (the client's) property, their baby," which this lawyer stated should justify the client's decision to enforce IP rights as aggressively as necessary in order to protect its property interests.

\section{Zealous Advocacy}

Lastly, many of the lawyers. also justified enforcing even weak IP claims on the basis that it is a lawyer's ethical duty to zealously represent clients' interests. As one lawyer explained:

115. See, e.g., 2 J. ThOMAS MCCARTHY, MCCARTHY ON TRADEMarks AND UNFAIR COMPETITION 11-249 to -250 (4th ed. 2011) (stating that trademark law imposes a duty on owners to police the market for infringers, and that the failure to do so can limit or destroy the owner's rights); see also Grupo Gigante SA De CV v. Dallo \& Co., Inc., 391 F.3d 1088, 1102 (9th Cir. 2004) (discussing the need for trademark owners to police against third party users or risk losing rights under theories of genericness or abandonment). Michael S. Mireles, Jr. analyzes how trademark law encourages owners to enforce marks vigorously in order to broaden the scope of trademark protection. Michael S. Mireles, Jr., Towards Recognizing and Reconciling the Multiplicity of Values and Interests in Trademark Law, 44 IND. L. REV, 427 (2011).

116. See 2 William F. PATRY, PATRY ON COPYRIGHT 5-340 (2011) ("Unlike trademarks, where the rights arise by use and may lapse by nonuse, copyright owners need not use or enforce their rights."). 
"A:That's my job. If the client wants me to do it, and if it's not clearly unlawful, I, as a lawyer, have a duty to be a zealous advocate on the client's behalf. I have an ethical duty to do so." 117

Thus, the IP lawyers in this study had several practical and ready means of justifying aggressive trademark and copyright enforcement when necessary - and even when enforcing admittedly weak legal claims. Indeed, the rhetoric of zealous advocacy allowed the lawyers broad scope to characterize such enforcement efforts as a professional and ethical virtue. ${ }^{118}$

\section{Do the IP "Haves" Come Out Ahead?}

The interviewed lawyers were also asked whether they perceived any advantages for clients who were regular enforcers of trademarks and copyrights- "repeat players" in the IP disputing process. ${ }^{119}$ This line of questioning builds on insights theorized by Marc Galanter in his influential article analyzing how and why repeat litigants may gain strategic advantages in the disputing process, particularly when disputing against "one-shot" users of the legal system. ${ }^{120}$ While Galanter's interests and insights apply particularly to litigation in the court system, ${ }^{121}$ this study examines how they might resonate in the context of informal negotiations in the IP disputing process.

\section{Reputational Advantage}

Many of the lawyers agreed that there were advantages for repeat trademark and copyright enforcers. First, repeat player IP enforcers may gain a reputational advantage from becoming known as a frequent claimant, particularly if they were known to be an

117. See supra text accompanying note 82 .

118. See, e.g., Kimberly Kirkland, Ethics in Large Law Firms: The Principle of Pragmatism, 35 U. MEM. L. REV. 631, 633-34,723-25 (2005) (discussing how pragmatic reasoning and ready access to rhetorical justifications, such as the need to "zealously" represent clients, shapes much lawyer ethical decision-making).

119. See Marc Galanter, Why the "Haves" Come Out Ahead: Speculations on the Limits of Legal Change, 9 LAW \& SOC'Y REV. 95, 98, 124-25 (1974) (theorizing how "repeat player" litigants have strategic advantages in the legal system over "one shot" actors who may not litigate frequently); see also IN LITIGATION: Do THE "HAVES" STILl COME OUT AHEAD? 6-9 (Herbert M. Kritzer \& Susan S. Silbey eds., 2003).

120. See sources cited supra note 119.

121. Galanter and many of the scholars who have empirically tested the repeat-player hypothesis are interested in examining how a system of justice that provides for formal equality between disputants can operate to the disadvantage of some of them, particularly one-shot users of the legal system. Id. 
"aggressive" enforcer of IP rights. ${ }^{122}$ The lawyers stated that having such a reputation itself had a potential prophylactic effect of deterring would-be infringers and thereby strengthening the owner's IP rights. The lawyers also stated that they believed opposing counsel who represented targets in trademark and copyright dispute negotiations took them and their clients more seriously when opposing counsel understood that the IP owners were regular enforcers of their rights. In fact, several of the lawyers stated that they made sure to stress their clients' previous experiences-and successes-in IP enforcements in and out of court during the course of negotiating with opposing counsel. One lawyer explained as follows:

A:I tell the other side how my client, [client name], has done this before, that it takes this seriously. They know who [client name] is, but doesn't hurt to remind them.

Q:Does that help? How does it?

A: It seems to. All I can say is that opposing counsel seems to take this client seriously. My last case, the guy says "I get it, we both know you're serious, let's figure out what will make this go away." So you can maybe read into that, but my point is I do feel it's effective and helps. ${ }^{123}$

Another lawyer put it similarly:

Q: Do you tell the other side your client has enforced its rights before? I mean during the phone call to follow up on the letter, the demand letter, like you just mentioned.

A:I think that usually is something I say. I generally say it in the letter, too.

Q: Why do you do that?

A: To keep them focused on the fact that my client takes its IP seriously and won't go away until we get a settlement. He needs to tell his client this won't go away by ignoring us, we mean business. ${ }^{124}$

122. For similar findings in a recent study of disputing in the World Trade Organization, see Joseph A. Conti, Learning to Dispute: Repeat Participation, Expertise, and Reputation at the World Trade Organization, 35 LAW \& SOC. INQUIRY 625, 626 (2010).

123. See supra text accompanying note 82 .

124. Id. 


\section{Repeat Player Experience as Advantage}

The interviewed lawyers also identified a second advantage that may stem from repeat player status, something often referred to as "the experience factor." The lawyers expressed a belief that having both a lawyer and client that are routinely involved in enforcing trademark and copyright claims provided both with advantages stemming from their deeper understanding as to what can and can't work in the IP disputing process. In addition, it provided greater expertise on the relevant law, insight into the types of circumstances that might constitute infringement, and how they might be handled effectively. When asked to explain, one lawyer expressed her belief that her trademark clients especially understood how far they can push smaller companies and individual enforcement targets. Another lawyer agreed, but also stressed that deep experience in the disputing process provided his client greater confidence when enforcing trademarks and copyrights, even against large company targets.

\section{Selective Enforcement as Advantage}

One additional repeat-player advantage identified by the interviewed lawyers is the clients' ability to selectively enforce their IP rights. This was described as the ability to "choose your fights," to select enforcement targets based in part on an understanding as to whether the dispute would likely be routine or entail undue risk. The example that most often came up when discussing this topic was cases involving apparent strong defenses to infringement, such as fair use in copyright or a defense based on parody in trademark law. Several lawyers stated that their clients learned over time that such cases could be challenging to enforce and sometimes bring unwanted negative publicity, so they sometimes took this into account and focused on easier targets.

\section{E. Resistance Is Not (Necessarily) Futile: Limits on IP Enforcement}

One of the more prominent themes from the lawyer interviews is the practical limit of trademark and copyright enforcement. Although many of the lawyers agreed that their trademark and copyright clients can-and do, sometimes-enforce even weak IP rights successfully, they also frequently qualified such statements by indicating that there are limits to enforcement efforts. The lawyers often remarked that they were aware that enforcement can bring unwanted negative publicity. And they stated that while some clients have little concern 
about negative publicity concerning their IP enforcement effortsindeed, some relish their reputation for being an aggressive IP enforcer-others have a strong aversion to such publicity. Thus, the interviewed lawyers discussed how they provided legal advice based on an understanding of any particular client's sensibilities regarding publicity. ${ }^{125}$

All of the interviewed lawyers were aware of such online forums as the Chilling Effects Clearinghouse, which collect and post online copies of cease and desist letters to publicize (and mock) what they consider to be un-warranted and overly aggressive assertions of IP rights. As one interviewed lawyer stated: "You always know that a letter you send can be on the Internet that same day, so you write it accordingly." The interviewed lawyers discussed how, for some clients, they needed to balance the need to enforce rights with the need to not alienate the client's customers and fans. One movie studio lawyer described this as follows:

A:Look, these fan sites [online fan web pages containing unauthorized copyrighted materials] are free publicity to some extent. Plus, they're fans after all. They buy your product and you want to keep good relations with these people. You don't want to sue them or harass them unless you have to.

Q: So these sometimes help create buzz or goodwill towards your client's movies?

A:Yes, sure. These are mostly homage sites. They drive business to us. Create a good vibe. We want that.

Q: Then why stop them, go after them?

A: To protect the property.

Q:But you said you don't do it all the time, so when do you?

A: When they try to commercialize the product. When they use it in an unsavory way. But otherwise, we like to work with these sites. When we tell them how they might be hurting the product,

125. Leah Chan Grinvald discusses some of the conditions that may make "shaming" of trademark "bullies" an effective extra-legal tactic to resist non-meritorious disputes. Grinvald, supra note 4, at 664-76. This is consistent with the finding of the present study-shaming tactics may work, but only for those IP owners that have determined that negative publicity about their enforcement practices outweighs the reputational benefits of being known as a strong enforcer of IP rights. 
they often agree to take it down themselves. ${ }^{126}$

This notion of balancing came up in discussing both trademarks and copyrights. It reflects the interviewed lawyers' awareness that there are risks to enforcement efforts in terms of costs and unwanted publicity that can harm a client's reputation and undermine the goodwill some clients generate with their IP. These lawyers discussed how they and their clients develop a sense of how best to make this balance work given the need to both disseminate the trademarks and copyrights publicly in order to increase their value, while at the same time negotiating ways to limit uses of this IP by others that may undermine that value. ${ }^{127}$

\section{CONCLUSION}

The pretrial IP disputing process is an under-studied and undertheorized arena of legal activity despite the fact that it is where most trademark and copyright enforcement takes place in everyday practice. This study of how and why IP lawyers advise their clients in trademark and copyright disputes is one of the first efforts to map and explore these everyday practices and their likely effects on free speech, creativity, and competition in the marketplace.

Perhaps the most striking finding of this study is that trademark and copyright lawyers and their clients sometimes enforce admittedly weak IP claims precisely because it can be an effective strategy with few downsides. As this study shows, aggressive trademark and copyright enforcement efforts often work, as enforcement targets frequently choose to capitulate or settle rather than resist claims on the legal merits, likely due to the costs and uncertainties inherent in IP litigation. Thus, this study supports the thesis that trademarks and copyrights can be and often are over-enforced in everyday legal practice. The lawyers in this study had few ethical concerns about enforcing even weak trademark and copyright claims, as the uncertainties of law and an asserted ethical duty to zealously advocate client interests were readily invoked to justify aggressive policing of IP rights. While this study also delineates some of the perceived

126. See supra text accompanying note 82 .

127. See, e.g., David S. Wall, Policing Elvis: Legal Action and the Shaping of PostMortem Celebrity Culture as Contested Space, 2 ENT. L. 35, 36-37 (2003) (in a related area of law, discussing how right of publicity owners must balance the need to police unauthorized uses of the celebrity image with the need to circulate the image in order to increase the awareness of and goodwill associated with it). 
advantages that "repeat player" IP owners may enjoy when enforcing their IP rights, it also demonstrates some of the factors that limit the ability and willingness of IP owners to enforce their rights. Trademark and copyright owners may be able to "bully" enforcement targets, but only when they do not fear the backlash of negative publicity and public opinion that can accompany such efforts. Future empirical scholarship that focuses on IP disputing in action should build on these insights and contribute to a growing understanding of the significance of private disputing in shaping the effective scope of trademark and copyright owners' rights. 